\title{
Tekstil İmalat Endüstrisinde İş Güvenliği Liderliği, İklimi ve Davranışı Arasındaki İlişkinin İncelenmesi
}

\author{
Çağdaş Çalış ${ }^{1 *}$, Banu Yeşim Büyükakınc1 ${ }^{2}$ \\ 1* İstanbul Aydın Üniversitesi, Lisansüstü Eğitim Enstitüsü, İş Sağlı̆̆ı ve Güvenliği Ana Bilim Dalı, İstanbul, Türkiye (ORCID: 0000-0002-8347-3748), \\ cagdascalis@stu.aydin.edu.tr \\ 2 İstanbul Aydın Üniversitesi, Mühendislik Fakültesi, Tekstil Mühendisliği Bölümü, İstanbul, Türkiye (ORCID: 0000-0001-7597-4406), \\ yesimbuyukakinci@aydin.edu.tr
}

(İlk Geliş Tarihi 3 Mayıs 2021 ve Kabul Tarihi 15 Ağustos 2021)

(DOI: 10.31590/ejosat.932037)

ATIF/REFERENCE: Çalış Ç. \& Büyükakıncı, B.Y. (2021). Tekstil İmalat Endüstrisinde İş Güvenliği Liderliği, İklimi ve Davranışı Arasındaki İlişkinin İncelenmesi. Avrupa Bilim ve Teknoloji Dergisi, (27), 44-52.

\section{$\ddot{O} \mathbf{z}$}

İş güvenliği lideri, iş güvenliği faaliyetlerinin her aşamasında bulunan kişidir. İş güvenliği lideri yalnızca çalışanların refahını ve güvenliğini değil, iş yerindeki olumlu iş güvenliği iklimini oluşturmada da rol üstlenmektedir. İş güvenliği liderliği ve iklimi, iş güvenliğinde performans çıktısı olarak değerlendirilen güvenli davranışı etkileyecek önemli unsurlardandır. İş yerlerinde güvenli davranışın sergilenmesi iş kazalarının azalmasına katkı sağlayacaktır. Bu çalışmada iş güvenliği liderliği, iş güvenliği iklimi ve güvenli davranış arasındaki ilişkilerin korelasyon yöntemi ile incelenmesi amaçlanmıştır. Sosyal Güvenlik Kurumu (SGK) 2019 istatistik y1llı̆̆ına göre en çok iş kazası yaşanan endüstrilerden biri olan tekstil imalat endüstrisinde gerçekleştirilmiştir. İş güvenliği liderliği, iş güvenliği iklimi ve güvenli davranış ölçekleri kullanılarak tekstil imalat endüstrisinde çalışan 416 kişi ile anket çalışması yapılmıştır. Anketlerin analizinde ve yorumlanmasında IBM SPSS Statistics 22, Lisrel 8.8 ve AMOS paket programları kullanılmıştır. Analizler sonucunda elde edilen bulgulara göre iş güvenliği liderliği ile iş güvenliği iklimi eylem boyutu arasında orta düzeyde anlamlı ilişki tespit edilmiştir. Bu da iş güvenliği liderliği seviyesi arttıkça iş güvenliği iklimi eylem boyutunun da artacağı sonucunu ortaya çıkarmaktadır. Aynı benzer ilişki iş güvenliği liderliği ile güvenli davranış arasında da görülmektedir. İş güvenliği liderliğinin seviyesinin yüksek olduğu işletmelerde çalışanların sergiledikleri güvenli davranışların da arttığı bu çalışma ile söylenebilir. Bunlara ek olarak iş güvenliği iklimi ile güvenli davranış arasındaki ilişkilerin çok zayıf kaldığı tespit edilmiştir.

Anahtar Kelimeler: İş güvenliği liderliği, İş güvenliği iklimi, Güvenli davranış, Tekstil imalat endüstrisi, İşçi sağllğı ve iş güvenliği.

\section{Investigation of Relationship Between Safety Leadership, Climate and Behavior in the Textile Manufacturing Industry}

\begin{abstract}
The safety leader is person who is involved in all stages of occupational safety activities. Person plays a role not only in the wellbeing and safety of employees, but also in creating a positive safety climate in the workplace. Safety leadership and climate are significant factors which will affect employees' safety behaviors which is considered as a performance output in occupational safety. The aim of this study is to relationship between safety leadership, safety climate and safety behavior. This study was conducted in the textile manufacturing industry, which is one of the sectors with the highest numbers of occupational accident occurrence according to the 2019 SSI statistical annuals. A survey was conducted with 416 people working in the textile manufacturing industry by use safety leadership, safety climate and safety behavior scales. IBM SPSS Statistics 22, Lisrel 8.8 and AMOS analysis package programs were used to interpret the questionnaires. According to the research findings, a moderately significant correlation was found between safety leadership and action dimension of safety climate. This shows us that as the level of safety leadership increases, the level of safety climate will also increase. The similar relationship is seen between safety leadership and safety behavior, too. With this study, it can be said that the safety behaviors of the employees in the business where the level of safety leadership is high also increases. Additionally, it has been determined that the relationship between safety climate and safety behavior is very weak.
\end{abstract}

Keywords: Safety leadership, Safety climate, Safety behavior, Textile manufacturing industry, Occupational health and safety

*Sorumlu Yazar: cagdascalis@stu.aydin.edu.tr 


\section{Giriş}

Sanayi devrimi ile gelişmiş ülkelerin ekonomik iyileşmelerinde tekstil endüstrisi önde gelen bir role sahip olmuştur. Türkiye'de tekstil endüstrisi, sağladığı istihdam ve ihracat ile ülkemize dış ticaret katkısı veren nadir sektörlerden birisidir (Efe, 2018). 2020 yılı sonu itibariyle ise tekstil sanayi mamulleri ihracatı $\% 10,97$ olup birinci otomotiv endüstrisi ve ikinci kimyevi maddeler ve mamullerinden sonra ihracatta üçüncü sıradadır (TİM, 2020). Türk hazır giyim sektörü ise 2019 yılı itibariyle \%3,3 pay ile dünyanın 7'inci büyük hazır giyim ihracatçısı konumundadır (Ticaret Bakanlığ İhracat Genel Müdürlüğü, 2020). Bununla beraber tekstil sektöründeki dünya çapındaki bu artmış rekabet ve çalışma ortamındaki olumsuz koşullar iş kazalarını da beraberinde getirmiştir (ÇSGB İSGGM, 2017). SGK tarafindan yayınlanmakta olan istatistik yıllıklarına bakıldığında tekstil ürünleri imalatında iş kazası sayıları son 5 yılda (2015-2019) artış eğilimi göstermiştir (Şekil 1).

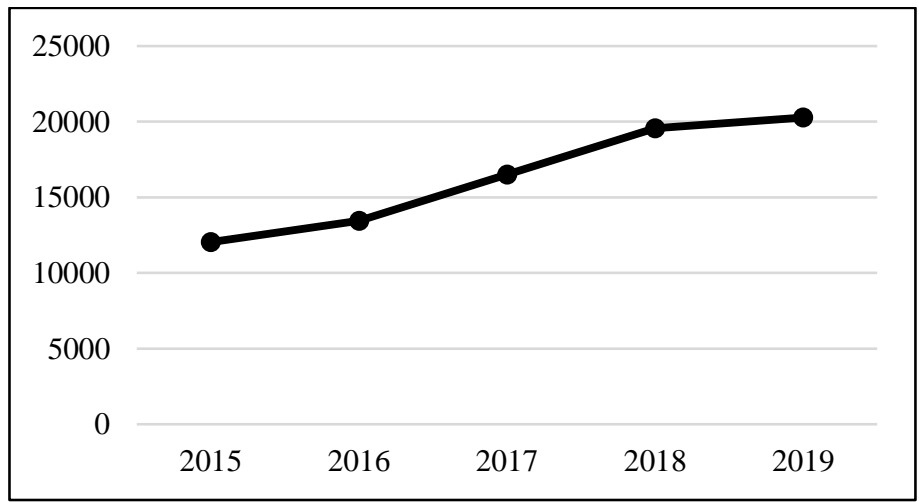

Şekil 1. Tekstil ürünleri imalatında 2015-2019 yılları arasında meydana gelen iş kazası sayıları (SGK, 2020).

Tekstil ürünleri imalatı, iş kazası meydana gelme sıralamasında ise 2015-2019 yılları arasında diğer ekonomik faaliyet sınıflarına göre sıralandığında hep üst sıralarda yer almıştır (Tablo 1).

Tablo 1. Tekstil ürünleri imalatını 2015-2019 yılları arasında iş kazası sayısına göre sektörlerdeki sıralaması (SGK, 2020).

\begin{tabular}{c|c}
\hline Yll & Sektörlere göre siralama \\
\hline 2015 & 5 \\
2016 & 5 \\
2017 & 6 \\
2018 & 6 \\
2019 & 5 \\
\hline
\end{tabular}

Tekstil ürünleri imalatı endüstrisindeki iş kazalarının azaltılmasında, çalışanları güvenli davranışa sevk edecek ve iş yerindeki iş güvenliği iklimini olumlu şekilde etkileyecek kişilere ihtiyaç duyulduğu açıktır. Bu konuda Mullen \& Kelloway (2009) tarafindan yapılan çalışmada, liderlerin güvenli çalışma davranışını ve uygulamalarını aktif olarak desteklemediğinde iş güvenliği iklimi algısının olumsuz bir şekilde etkilendiğini göstermiştir.

Zayıf güvenlik kültürünün bir çıktısı olan iş kazalarında, sayıların azaltılması için, ISG mevzuatında yapılan düzenlemelerin yanında çalışanların bilinçlendirilerek, çalışma ortamındaki tehlikeli davranışları ortadan kaldırmak gereklidir
(Olcay, 2021; Olcay ve diğ. 2021). Tekstil sektöründe yaşanan iş kazaları ile ilgili yapılan çalışmalar incelendiğinde Ergin \& Mergen (2017) tarafından yürütülen çalışmada, tekstil sektöründe iş kazalarının \%68,1'inin tehlikeli davranışlardan kaynaklandığ 1 ortaya konmuştur. Tekstil sektöründeki iş güvenliği liderliğinin güçlendirilmesi, güvenli çalışma davranışının desteklenerek iş güvenliği iklimi algısının artmasını sağlayacaktır. Bu destek ve güçlendirme, tekstil sektöründeki iş kazalarının azaltılmasına katkı sağlaması açısından önem taşımaktadır.

\section{1. İş Güvenliği Liderliği}

İş güvenliği liderliği örgütsel liderliğin bir alt başlığ1 olmakla birlikte iş güvenliği liderliği kalitesinin, örgüt liderliğinin kalitesi üzerinde etkisi vardır (Wu, 2005). İş güvenliği liderliği, acıların azaltılması ve insan yaşamı için özen göstermek, endişe etmek olarak tanımlanabilir (Casey \& Griffin, 2020). Hackitt (2013), iş güvenliği liderliğinin ön plana çıkarılmadığı ve merkeze oturtulamadığı iş yerlerinde İSG yönetim sisteminin diğer ana parçalarına da sahip olunamayacağını dile getirmiştir. Cooper (1998) ise iş güvenliği liderliğinin yöneticiler yoluyla gösterilen, örgütteki tüm kişilerin iş güvenliği konularını nasıl karşılayacağı ve bunlara nasıl karşı durulacağını tayin ettiği için olumlu etkisi olan mühim bir özellik olduğunu söylemiştir. İş güvenliği liderliğinin kavramlaştırılmasına, iş güvenliği iklimi ve kültürü çalışmaları dolaylı olarak referans vermesine karşın, iş güvenliği liderliği ile ilgili çalışmalar oransal olarak çok azdır (Hofmann \& Morgeson, 2004). Bu sebeple iş güvenliği liderliğiyle alakalı çalışmalar örgüt liderliği çalışmalarını baz almakta ve iş güvenliği liderliği çalışmalarının çoğu, lider-üye etkileşimi modeli, etkileşimci (transaksiyonel) liderlik ve dönüştürücü (transformasyonel) liderliğe dayanmaktadır (Donovan, Salmon \& Lenné, 2016; Mirza \& Isha, 2017; Pilbeam vd., 2016).

\section{2. İş Güvenliği İklimi}

Örgüt iklimi kavramı, işletmelerin yönetilmesinde çalışan ilişkileri problemleri üstüne 1930'lu yıllarda çalışılırken gündeme gelmiş ve 1960-70 yılları arasında fazlasıyla rağbet görmüştür (Dursun, 2012; Şişman, 2014). Kavramın, örgüt kültürünün bilinmesiyle birlikte popüler hale geldiği söylense de (Şişman, 2014) örgüt iklimi, örgüt kültüründen 25 yıl önce Lewin K.'nın 1940-50'li yıllarda çalıştığı alan kuramına dayanmaktadır (Ashkanasy \& Jackson, 2009). Örgüt iklimi ile ilgili birçok tanım yapılmış olsa da Türkiye'de örgüt iklimiyle ilgili ilk çalışmalardan birini yapan Yücel Ertekin örgüt iklimini, “örgüte kimliğini kazandıran, görevlilerin davranışlarını etkileyen ve onlar tarafindan algılanan, örgüte egemen olan tüm özellikler dizisi”" şeklinde tanımlamıştır (Kurt \& Çalık, 2010). İş güvenliği iklimi ise örgüt ikliminin bir alt kavramı olarak kabul edilir (Coyle, Sleeman \& Adams, 1995) ve iş yerinde verimliliğe karşı iş güvenliğinin göreli önemi veya önceliği ile ilgili uzlaşmaya dayalı veya paylaşılan sosyal biliş olarak tanımlanır (Hofmann, Burke \& Zohar, 2017). İş güvenliği ikliminin, iş kazalarını azaltmada değerinin bulunmasıyla beraber boyutluluğu ve faktör yapısı ile ilgili tartışmalar devam etmektedir. Araştırmacılar, iş güvenliği ikliminin tek boyuta sahip, görülemeyen bir değişken olması gerektiğini savunurken diğer araştırmacılar tabiatı gereği çok boyutlu olduğunu ifade etmişlerdir (Bosak, Coetsee \& Cullinane, 2013). İş güvenliği ikliminin boyutları, araştırılmaya devam etmekle birlikte hala belirsizliğini korumaktadır (Alruqi, Hallowell \& Techera, 2018). 
Ancak Zohar (2000) grup seviyesinde iş güvenliği ikliminin, iki boyutta olabileceğini ifade etmiştir:

1. Eylem: yöneticinin, çalışanların davranışlarına olumlu/olumsuz geri bildirimi ve iş güvenliği konularıyla ilgili eylemin başlamasıyla ilgilidir.

2. Beklenti: eylemden ziyade yönetimin iş güvenliği iklimini oluşturmasıyla ilgili beklentiyle ilgilidir.

\section{3. İş Güvenliği Davranışı}

Bir organizmanın yaptığı şeylerin tamamı davranış olarak isimlendirilir. Davranış sadece kolu kaldırma, konuşma gibi fiziki olarak görülen eylemler değil, ayrıca hem düşünme ve hissetme hem de hatırlama eylemlerini de içermektedir (Ramnerö \& Törneke, 2017). Davranışlar, görevin yerine getirilip bitirilmesine öncülük etmek için her şeyi bir araya getiren bileşenlerdir (BSMS, 2020).

Çalışanların iş yerinde göstermiş olduğu davranışlar, iş güvenliği performansını belirlemede kullanılan unsurlardan biridir (Neal \& Griffin, 2002). Bu unsurlar, bir görevle ilgili davranışların ana boyutlarını yansıtır (Neal, Griffin, \& Hart, 2000). İş güvenliğinde davranışın ana boyutu uyum ve katılım olmak üzere iki ana boyutta tanımlanmıştır (Griffin \& Neal, 2000). İş güvenliğinde uyum davranışı direkt iş kazasıyla alakalı iken, katılım davranışı iş kazasıyla direkt ilişkisi düşük olan iş güvenliği davranışıdır (Moon, Lee, \& Oah, 2013).

\section{Materyal ve Metot}

\subsection{Veri Toplama}

Çalışmanın evrenini, 2019 yılı SGK istatistik yıllığında yer alan Tekirdağ ilinde tekstil imalat sektöründeki 401 iş yerinde bulunan 46.056 sigortalı çalışan oluşturmaktadır (SGK, 2020). Evrenin örneklemini belirlemek için aşağıdaki formüller kullanılmıştır (Lorcu, 2015).

$n=\frac{n_{0}}{1+\frac{n_{0}-1}{N}}$

$n_{0}=\frac{t^{2} \times p \times(1-p)}{d^{2}}$

n: örneklem büyüklüğü, $N$ : ana kütle büyüklüğü, t: güven düzeyine karşılık t değeri, p: belli bir özelliğe sahip birimlerin oranı, d: tahmini tolerans miktarı (hata pay1)

$\% 5$ hata payı ile ana kütleyi temsil edecek örneklem büyüklüğü:

$n_{0}=\frac{1,96^{2} \times 0,5 \times(1-0,5)}{0,05^{2}}=384,16$

$n=\frac{384,16}{1+\frac{(384,16-1)}{46056}} \cong 380,99$

Örneklemin hesaplanması sonucunda 381 çalışana ulaşılması durumunda, çalışmanın evreni temsil edebileceği görülmüştür. Çalışmanın örnekleminin meydana getirilmesinde ise örnekleme yöntemi olarak tesadüfi olmayan örnekleme yöntemlerinden kolayda örnekleme yöntemi tercih edilmiştir.
Kolayda örnekleme, evren içerisinden örneklem seçiminde araştırmacı tarafından belirlenen tesadüfî olmayan örnekleme yöntemidir. Kolayda örneklemede veriler, evrenden en kolay, hızlı ve ekonomik şekilde toplanabilmektedir. Türkiye'de yapılan çalışmaların yaklaşık \%90'nında kolayda örnekleme yöntemi kullanıldığı ifade edilmektedir (Haşıloğlu, Baran \& Aydin, 2015).

Çalışmanın gerçekleştirilebilmesi için İstanbul Aydın Üniversitesi Etik Komisyonu'nun 17.12.2019 tarihli ve 2019/22 sayılı kararıyla Etik Onay alınmıştır. Alınan onay akabinde tesadüfi olmayan örnekleme yöntemi ile Tekirdağ ilindeki tekstil imalat sektöründe faaliyet gösteren üç iş yeri seçilmiştir. $\mathrm{Bu}$ işletmelerde 495 kişiyle anket gerçekleştirilmiş, 79 anket eksik bilgi girişi, yanlış kodlama nedeniyle geçersiz sayılıp 416 anket analize dahil edilmiştir. Anket demografik bilgiler, iş güvenliği liderliği ölçeği, iş güvenliği iklimi ölçeği ve iş güvenliği davranış ölçeği olmak üzere 4 bölümden oluşmaktadır.

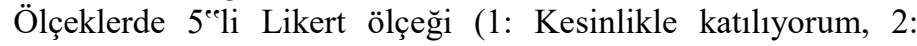
Katılıyorum, 3: Kararsızım/Bilgim Yok, 4: Katılmıyorum, 5: Hiç katılmıyorum) kullanılmıştır.

\subsection{1. İş Güvenliği Liderlik (IGL) Ölçeği}

Çalışanların amirlerinin liderliğinin belirlenmesinde $\mathrm{Wu}$ (2005) tarafindan geliştirilen toplam 45 maddeden oluşan ölçek tercih edilmiştir. Ölçek, yazar tarafından Türkçeye çevrilmiştir. $\mathrm{Bu}$ ölçekte "İşs güvenliği faaliyetini dürüst bir şekilde yürütebilir.”, "İş güvenliği faaliyetini yürütürken çalışanlara sevecen davranır.", "Çalışanlar iş güvenliği faaliyetini yerine getirdiklerinde onları takdir eder.”, "İş güvenliği konusunda iyi bir performans sergileyenleri terfi ettirir." gibi ifadeler bulunmaktadır.

\subsection{2. İş Güvenliği İklim (İGi) Ölçeği}

Çalışanların amirlerinin liderliğinin belirlenmesinde $\mathrm{Wu}$ (2005) tarafından geliştirilen toplam 45 maddeden oluşan ölçek tercih edilmiştir. Ölçek, yazar tarafından Türkçeye çevrilmiştir. $\mathrm{Bu}$ ölçekte "İşs güvenliği faaliyetini dürüst bir şekilde yürütebilir.", "İş güvenliği faaliyetini yürütürken çalışanlara sevecen davranır.", "Çalışanlar iş güvenliği faaliyetini yerine getirdiklerinde onları takdir eder.", "İş güvenliği konusunda iyi bir performans sergileyenleri terfi ettirir." gibi ifadeler bulunmaktadır.

\subsection{3. İş Güvenliği Davranış (IGD) Ölçeği}

İş güvenliği davranış ölçeği olarak Neal, Griffin ve Hart (2000) tarafindan geliştirilen toplam 6 maddeden oluşan ölçek tercih edilmiştir. Sorular yazar tarafindan Türkçeye çevrilmemiş olup Dursun (2012) tarafından Türkçeye çevrilen sorular kullanılmıştır. $\mathrm{Bu}$ ölçekte "İşimi yaparken uygun güvenlik prosedürlerini kullanırım.”, "İ̧s yeri güvenliğinin iyileştirilmesi için fazladan çaba harcarım." gibi ifadeler bulunmaktadır.

\subsection{Verilerin Analizi}

Anketler aracılığıyla elde edilen verilerin istatistik analizlerinin yapılmasında IBM SPSS Statistics 22, Lisrel 8.8 ve AMOS istatistik paket programları kullanılmıştır. Anlamlılık en az $\mathrm{p}<0,05$ seviyesinde yapılmıştır. Çalışmada tercih edilen ölçeklerin öncelikle güvenilirlik, keşfedici ve doğrulayıcı faktör analizleri yapılmıştır. Keşfedici faktör analizine uygunluk konusunda ilk olarak KMO (Kaiser Meyer Olkin) değeri ve sonrasında Bartlett küresellik test değerleri incelenmiştir. KMO, örneklemin yeterlilik değerini ifade etmektedir (Can, 2019). 
Bartlett'in Küresellik Testinde ise p sayısının 0,05'ten küçük çıkması durumunda ise verilerden faktör çıkarılabilecektir. (Şencan ve Fidan, 2020). KMO değerinin aldığı değerlere göre yeterlilik aralıkları Tablo 2'deki gibidir.

Tablo 2. KMO Yeterlilik Aralıkları (Altunışık vd., 2005; Sharma, 1996; Tavşancıl, 2002).

\begin{tabular}{c|c}
\hline Yeterlilik & KMO Ölçüt Aralıkları \\
\hline Mükemmel & $0,90-1,00$ \\
Oldukça iyi & $0,80-0,89$ \\
İyi & $0,70-0,79$ \\
Orta & $0,60-0,69$ \\
Zayıf & $0,50-0,59$ \\
Kabul edilemez & $<0,50$ \\
\hline
\end{tabular}

Tercih edilen ölçeklerin geçerlilik analizlerinde doğrulayıcı faktör analizi kullanılmıştır (Aytaç ve Öngen, 2012). Doğrulayıcı faktör analizinin geçerli olduğunu ifade edebilmek için modele ait uyum indekslerin katsayılarının (Tablo 3) kabul edilebilir seviyede olması beklenir. Uyumu iyi olan modeller birçok farklı indekste, bazen de hepsinde, tutarlı sonuçlar vermektedir. Bununla beraber CFI ve RMSEA en sik rapor edilen uyum indeksleridir (Ullman, 2015).

Tablo 3. Uyum Indeksleri (Demir ve Akengin, 2010; Dursun ve Kocagöz, 2010; Temel, 2020; Tezcan, 2008).

\begin{tabular}{c|c}
\hline Uyum Indeksleri & Kabul Edilebilir Uyum Aralıkları \\
\hline RMSEA & $\leq 0,10$ \\
NFI & $\geq 0,90$ \\
NNFI & $\geq 0,90$ \\
CFI & $\geq 0,90$ \\
IFI & $\geq 0,90$ \\
RFI & $\geq 0,85$ \\
SRMR & $\leq 0,08$ \\
GFI & $\geq 0,90$ \\
AGFI & $\geq 0,85$ \\
X2/df & $<5$ \\
\hline
\end{tabular}

Güvenirliğin hesabında sıklıkla başvurulan yöntem olarak Cronbach Alfa Yöntemi (Seçer, 2015) tercih edilmiştir ve değerlendirilmesinde Tablo 4'ten faydalanılmıştır.
Tablo 4. Cronbach Alfa Katsayısı Güvenirlik Aralıkları (Karagöz, 2014).

\begin{tabular}{c|c}
\hline Güvenirlik & Alfa Kaysayısı Aralıkları \\
\hline Güvenilir değil & $0,00<0,40$ \\
Düşük güvenirlik & $0,40<0,60$ \\
Oldukça güvenilir & $0,60<0,80$ \\
Yüksek derecede güvenilir & $0,80<1,00$ \\
\hline
\end{tabular}

Ölçeklerdeki değişkenlerin birlikte değişimini açıklamak için korelasyon analizi kullanılmıştır (Lorcu, 2015). Korelasyonda amaç iki değişken arasındaki ilişkinin yönünü ve kuvvetini ölçmektir (Erilli, 2015). İki değişken arasındaki ilişkinin önemli özelliklerini açıklayan ve özetleyen $r$ ile gösterilen sayıya korelasyon katsayısı denir (Büyüköztürk, Çokluk \& Köklü, 2020). - 1 ile +1 arasında değer alan korelasyon katsayısı 1'e yakınlaştıkça ilişki o kadar fazla ve güçlü demektir. Korelasyon katsayısının işareti ise ilişkinin yönünü göstermektedir. Pozitif $(+)$ ilişki değişimin yönünün aynı olduğu yani değişkenlerden biri artıyorsa diğerinin arttığını; negatif (-) ilişki ise değişkenlerden birisi artarken diğerinin azaldığını ifade eder (Can, 2019). Korelasyon katsayısının sifir olması iki değişken arasında ilişki olmadığı durumdur (Taşpınar, 2017). Korelasyon katsayısının değerlendirilmesinde Tablo 5'ten yararlanılmıştır.

Tablo 5. Korelasyon Katsayısı (r) Değer Aralıkları (Karagöz, 2014).

\begin{tabular}{c|c}
\hline İlişki Büyüklüğ̈̈ & r Değeri Aralı̆̆ı \\
\hline Çok zayıf & $0-0,25$ \\
Zayıf & $0,26-0,49$ \\
Orta & $0,50-0,69$ \\
İyi & $0,70-0,89$ \\
Çok İyi & $0,90-1,00$ \\
\hline
\end{tabular}

\subsection{Hipotezler}

Hipotez, araştırmalarda test edilmek üzere geliştirilen, henüz gerçekliği kesin olmayan varsayım, iddia ve yargılara verilen isimdir (Akarsu ve Akarsu, 2019). Yani test edilebilir değişkenlerle gerçekleştirilir ve araştırmanın konusunu oluşturan sorunun çözümü ile ilgili “özgün” varsayım içerir (Bayat, 2010). Çalışmanın amacına uygun olarak bir sonuca ulaşılabilmesi için oluşturulan ana ve alt hipotezler Tablo 6'da belirtilmiştir.

Tablo 6. Ana ve alt hipotezler

\begin{tabular}{|c|c|c|}
\hline Ana Hipotez & Alt Hipotez & Hipotez Açıklaması \\
\hline$H_{l}$ & $\begin{array}{l}H_{l a} \\
H_{l b}\end{array}$ & $\begin{array}{l}\text { İş güvenliği liderliği ile iş güvenliği iklimi arasında pozitif olarak anlamlı bir ilişki vardır. } \\
\text { İş güvenliği liderliği ile iş güvenliği iklimi eylem faktörü arasında pozitif olarak anlamlı bir } \\
\text { ilişki vardır. } \\
\text { İş güvenliği liderliği ile iş güvenliği iklimi beklenti faktörü arasında pozitif olarak anlamlı bir } \\
\text { ilişki vardır. }\end{array}$ \\
\hline $\mathrm{H}_{2}$ & $\begin{array}{l}H_{2 a} \\
H_{2 b}\end{array}$ & $\begin{array}{l}\text { İş güvenliği liderliği ile iş güvenliği davranışı arasında pozitif olarak anlamlı bir ilişki vardır. } \\
\text { İş güvenliği liderliği ile iş güvenliği uyum davranışı arasında pozitif olarak anlamlı bir ilişki } \\
\text { vardır. } \\
\text { İş güvenliği liderliği ile iş güvenliği katılım davranışı arasında pozitif olarak anlamlı bir ilişki } \\
\text { vardır. }\end{array}$ \\
\hline $\mathrm{H}_{3}$ & $\begin{array}{l}H_{3 a} \\
H_{3 b}\end{array}$ & $\begin{array}{l}\text { İş güvenliği iklimi ile iş güvenliği davranışı arasında pozitif olarak anlamlı bir ilişki vardır. } \\
\text { İş güvenliği iklimi eylem faktörü ile iş güvenliği uyum davranışı arasında pozitif olarak anlamlı } \\
\text { bir ilişki vardır. } \\
\text { İş güvenliği iklimi eylem faktörü ile iş güvenliği katılım davranışı arasında pozitif olarak } \\
\text { anlamlı bir ilișki vardır. }\end{array}$ \\
\hline
\end{tabular}




$$
\begin{array}{ll}
H_{3 c} & \begin{array}{l}
\text { İş̧ güvenliği iklimi beklenti faktörü ile iş güvenliği uyum davranışı arasında pozitif olarak } \\
\text { anlamlı bir ilişki vardır. } \\
\text { İş güvenliği iklimi beklenti faktörü ile iş güvenliği katılım davranışı arasında pozitif olarak } \\
\text { anlamlı bir ilişki vardır. }
\end{array}
\end{array}
$$

\section{Araştırma Sonuçları ve Tartışma}

\subsection{Demografik Bulgular}

Çalışmaya katılan işletmelerdeki çalışanların demografik bulguları Tablo 7'de verilmiştir. Tablo incelendiğinde çalışmaya katılan çalışanların \%69,2'si $(n=288)$ erkeklerden, \%30,8'ü $(\mathrm{n}=128)$ kadınlardan oluşmaktadır. Yaş gruplarına bakıldığında \%23,6 17-30 yaş aralığında, \%59,9 31-44 yaş aralığında $\% 16,6$ 'sı da 45 ve yaş üstündedir. Katılımcıların yaşları 17-55 arasında değişmekte olup, ortalama yaş $36,80 \pm 7,53$ yıldır. Çalışma yapılan işletmelerden birinde çıraklık uygulaması olduğundan 17 yaşında bir katılımcı vardır. Çalışmaya katılanların \%83,4'ü $(n=347)$ evli, \%13,9'u $(n=58)$ bekar, \%2,6's1 (n=11) boşanmış/eşi vefat etmiştir. Çalışmaya katılanların eğitim durumlarına bakıldığında ise \%36,8'i $(n=153)$ ilkokul/ilköğretim mezunu, \%52,9'u $(n=220)$ lise mezunu, $\% 8$,2'si (n=34) lisans mezunu, \%2,2'si $(n=9)$ lisansüstü mezunudur. İşteki konumlarına göre ise katılımcıların \%92,3'ü $(\mathrm{n}=384)$ çalışan/operatör, \%7,7'si $(\mathrm{n}=32)$ yöneticidir. Çalışmaya katılanların \%14,7'si $(\mathrm{n}=61)$ mevcut iş yerlerinde iş kazası geçirdiğini iletmiştir. Mevcut iş yerlerinde iş güvenliği eğitimi alma durumlarına göre dağılımında ise çalışanların \%98,3'ü $(n=409)$ iş güvenliği eğitimi aldıklarını, \%1,7'si $(n=7)$ iş güvenliği eğitimi almadıklarını belirtmiştir. İş güvenliği eğitimine katılmayanların çalışan/operatör ve kıdemlerine bakıldığında ise bir kişinin 1 y1l, diğerlerinin 3 y1l ve üzeri zamandır mevcut işletmelerinde çalıştıkları tespit edilmiştir. Eğitime katılmayanlardan sadece bir kişi çalıştığ 1 işletmede iş kazası geçirmiş olup kıdemi 5 yıl, toplam iş tecrübesi ise 13 yıldır. Yapılan yüz yüze görüşmelerde ise çalışanlara neden iş güvenliği eğitimine katılmadıkları sorusu yöneltildiğinde üretim sıkışıklı̆̆l, bazı spesifik makinelerde çalışan kişilerin yedeğinin

\begin{tabular}{|c|c|c|c|c|c|c|c|}
\hline \multirow{2}{*}{ Demografik Değişkenler } & \multirow{2}{*}{ Aralıklar } & \multicolumn{2}{|c|}{ Erkek } & \multicolumn{2}{|c|}{ Kadın } & \multicolumn{2}{|c|}{ Toplam } \\
\hline & & $\mathrm{N}$ & $\%$ & $\mathrm{~N}$ & $\%$ & $\mathrm{~N}$ & $\%$ \\
\hline \multirow{3}{*}{ Yaş } & $17-30$ & 68 & 23,6 & 30 & 23,4 & 98 & 23,6 \\
\hline & $31-44$ & 156 & 54,2 & 93 & 72,7 & 249 & 59,9 \\
\hline & 45 ve üstü & 64 & 22,2 & 5 & 3,9 & 69 & 16,6 \\
\hline \multirow{4}{*}{ Eğitim durumu } & İlkokul/ilkögrretim & 104 & 36,11 & 49 & 38,28 & 153 & 36,8 \\
\hline & Lise & 160 & 55,56 & 60 & 46,88 & 220 & 52,9 \\
\hline & Lisans & 20 & 6,94 & 14 & 10,94 & 34 & 8,2 \\
\hline & Lisansüstü & 4 & 1,39 & 5 & 3,91 & 9 & 2,2 \\
\hline \multirow{3}{*}{ Medeni durum } & Evli & 235 & 81,6 & 112 & 87,5 & 347 & 83,4 \\
\hline & Bekar & 49 & 17,01 & 9 & 7,03 & 58 & 13,9 \\
\hline & Boşanmış / Eşi vefat etmiş & 4 & 1,39 & 7 & 5,47 & 11 & 2,6 \\
\hline \multirow{2}{*}{ Işteki konum } & Çalışan/Operatör & 267 & 92,71 & 117 & 91,41 & 384 & 92,3 \\
\hline & Yönetici & 21 & 7,29 & 11 & 8,59 & 32 & 7,7 \\
\hline \multirow{2}{*}{$\begin{array}{l}\text { Mevcut iş yerinde kaza geçirme } \\
\text { durumu }\end{array}$} & Evet & 42 & 14,58 & 19 & 14,84 & 61 & 14,7 \\
\hline & Hayır & 246 & 85,42 & 109 & 85,16 & 355 & 85,3 \\
\hline \multirow{3}{*}{ İş güvenliği ĕ̆itim alma durumu } & Evet & 282 & 97,92 & 127 & 99,22 & 409 & 98,3 \\
\hline & Hayır & 6 & 2,08 & 1 & 0,78 & 7 & 1,7 \\
\hline & Toplam & 288 & 100 & 128 & 100 & 416 & 100 \\
\hline
\end{tabular}
olmamasl ve sürekli benzer konuların anlatılması ve konuların zaten bilindiğ $i$ cevapları alınmıştır.

Tablo 7. Demografik Bulgular

\subsection{Geçerlilik ve Güvenirlik Bulguları}

Ölçeklerin keşfedici faktör analizinde Varimax rotasyonu uygulanmış olup faktör analizine tabi tutulmuştur. İş güvenliği liderliği ölçeğinde yükleri \%40'ın altında olan 2 soru (25 ve 33) analizden çıkarılmıştır. Faktör analizi uygulandığında iş güvenliği liderliği ölçeğinin tek faktör altında (varyansın \%46,32'sini açıklamaktadır), iş güvenliği iklimi ölçeğinin iki faktör altında (varyansın \%60,34'ünü açıklamaktadır), iș güvenliği davranış ölçeğinin iki faktör altında (varyansın \%77,92'sini açıklamaktadır) toplandığ 1 görülmüştür.
Tablo 8 incelendiğinde KMO değerinin İGL ölçeği için 0,965, İGİ ölçeği için 0,810 , İGD ölçeği için 0,826'dır. Bu sonuçlara göre ilgili değerlerin oldukça iyi ve verilerden analiz yapılması için uygun olduğu görülmektedir. Sonuçlar değerlendirildiğinde bu hipotez her iki ölçek için de anlamlılık $p<0,001$ düzeyinde reddedilmiştir. Buna göre maddeler arasında ilişkinin varlığını göstermek için faktör analizinin uygulanabileceği düşünülmektedir (Hair vd., 1998; Osmanoğlu vd, 2018). 
Tablo 8. IGGL, IGGI ve IGD Ölçeklerinin KMO ve Bartlett’s Küresellik Testi Sonuçları.

\begin{tabular}{lllll}
\hline & & IGL & IGI & İGD \\
\hline KMO Örneklem Yeterlilik Ölçümü & & 0,965 & 0,810 & 0,826 \\
\hline Bartlett's Küresellik Testi & Ki kare & 12860,762 & 1693,534 & 1387,428 \\
& Serbestlik derecesi & 903 & 45 & 14 \\
& Anlamllık & 0,001 & 0,001 & 0,001 \\
\hline
\end{tabular}

İGL, İGİ ve İGD ölçekleri için doğrulayıcı faktör analizine ait uyum ölçütleri Tablo 9'da verilmiştir. Sonuçlara göre uyum değerleri kabul edilebilir uyum göstermeleri sebebiyle verilerin kabul edilebilir uyuma sahip olduğu ve ölçeklerin istatistiki olarak anlamlı ve geçerli olduğu görülmüştür $(\mathrm{p}=0,001 ; \mathrm{p}<0,01)$.

Tablo 9. İGL, İGİ, IGD Ölçeklerinin Doğrulayıcı Faktör Analizi Uyum Ölçütleri.

\begin{tabular}{ccccccc}
\hline & \multicolumn{2}{c}{ İGL Ölçeği } & \multicolumn{2}{c}{ İGİ Ölçeği } & \multicolumn{2}{c}{ İGD Ölçeği } \\
\hline İndeksler & Sonuçlar & Uyum & Sonuçlar & Uyum & Sonuçlar & Uyum \\
\hline$R M S E A$ & 0,10 & K.E. & 0,097 & K.E. & 0,10 & K.E. \\
$N F I$ & 0,95 & K.E. & 0,93 & K.E. & 0,96 & K.E. \\
$N N F I$ & 0,96 & K.E. & 0,93 & K.E. & 0,95 & K.E. \\
$C F I$ & 0,96 & K.E. & 0,94 & K.E. & 0,96 & K.E. \\
$I F I$ & 0,96 & K.E. & 0,94 & K.E. & 0,96 & K.E. \\
$R F I$ & 0,95 & K.E. & 0,91 & K.E. & 0,92 & K.E. \\
$S R M R$ & 0,065 & K.E. & 0,075 & K.E. & 0,055 & K.E. \\
$G F I$ & 0,62 & - & 0,93 & K.E. & 0,94 & K.E. \\
$A G F I$ & 0,58 & - & 0,88 & K.E. & 0,84 & - \\
$X 2 / d f$ & 4,4 & K.E. & 4,6 & K.E. & 10,3 & - \\
\hline
\end{tabular}

Ölçeklerin güvenirlik değerleri ise Tablo 10 'da verilmiştir. İGL ölçeği güvenirlik değeri 0,972 olarak çıkmış olup, ölçek yüksek derecede güvenilir olarak belirlenmiştir. İGİ ölçeği güvenirlik değerini belirten Cronbach Alfa Katsayısı değerleri incelendiğinde; eylem faktörü 0,758 , beklenti faktörü 0,879 ve ölçek toplamı 0,717 olarak çıkmış olup, ölçeğin oldukça güvenilir çıktığı değerlendirilmişsir.

Tablo 10. IGGL, İGİ, IGD Ölçekleri Güvenirlik Değeri.

\begin{tabular}{cccc}
\hline & Madde Sayısı & Sorular & Cronbach's Alpha \\
\cline { 2 - 4 } Toplam İș Güvenliği Liderliği & 43 & $1-45(2$ soru hariç) & 0,972 \\
\hline Toplam İş Güvenliği İklimi & 10 & $1-10$ & 0,717 \\
Eylem Faktörü & 5 & $1,2,3,4,5$ & 0,758 \\
Beklenti Faktörü & 5 & $6,7,8,9,10$ & 0,879 \\
\hline Toplam İș Güvenliği Davranışı & 6 & $1-10$ & 0,878 \\
Uyum Faktörü & 3 & $1,2,3$ & 0,874 \\
Katıllm Faktörü & 3 & $4,5,6$ & 0,818 \\
\hline
\end{tabular}

\section{3. İliş ki Analizi Bulguları}

Tercih edilen ölçekler ve faktörleri arasındaki ilişkilerle ile ilgili korelasyon analiz sonucu Tablo 11'de verilmiştir.
Değişkenler normal dağılıma sahip olduğundan Pearson korelasyon analizi kullanılmıştır.

Tablo 11. IGLL, İGI, IGGD Ölçekleri Korelasyon Analiz Sonuçları.

\begin{tabular}{|c|c|c|c|c|}
\hline & & $\mathbf{r}$ & $\mathbf{p}$ & İlişsi \\
\hline IGGL Ölçeği & - $\quad$ IGGI Ölçeği & & & \\
\hline İGL Toplam & Eylem & 0,556 & $0,001 * *$ & Orta \\
\hline İGL Toplam & - Beklenti & $-0,120$ & $0,014 *$ & Çok zayıf \\
\hline IGGL Toplam & - $\quad \dot{I G I}$ Toplam & 0,444 & $0,001 * *$ & Zayıf \\
\hline IGL Ölçeği & - $\quad$ IGD Ölçeği & & & \\
\hline İGL Toplam & Uyит & 0,459 & $0,001 * *$ & Zayif \\
\hline İGL Toplam & - Katılım & 0,499 & $0,001 * *$ & Zayif \\
\hline İGL Toplam & - $\quad$ IGD Toplam & 0,534 & $0,001 * *$ & Orta \\
\hline İĠ Ölçeği & - $\quad$ IGGD Ölç̧ĕgi & & & \\
\hline Eylem & - Uyиm & 0,364 & $0,001 * *$ & Zayif \\
\hline
\end{tabular}




\begin{tabular}{lcccll}
\hline Beklenti & - & Uyum & $-0,195$ & $0,001 * *$ & Çok zayıf \\
Eylem & - & Katılım & 0,466 & $0,001 * *$ & Zayıf \\
Beklenti & - & Katılım & $-0,084$ & 0,086 & - \\
IGI Toplam & - & IGD Toplam & 0,413 & $0,001 * *$ & Zayıf \\
\hline r: Pearson korelasyon katsayisi & $* \mathrm{p}<0,05$ & $* * \mathrm{p}<0,0$ & &
\end{tabular}

r: Pearson korelasyon katsayısı $\quad * \mathrm{p}<0,05$

$* * \mathrm{p}<0,0$

İş güvenliği liderlik ölçeği ile iş güvenliği iklimi ölçeği puanları ilişkisi;

İş güvenliği liderlik ölçeği toplam puanı ile iş güvenliği iklimi ölçeği toplam puanı arasında pozitif yönlü (toplam liderlik olarak puan arttıkça, iş güvenliği iklimi eylem boyutu puanı da artar) istatistiki olarak anlamlı zayıf iliş̧i saptanmıştır $(\mathrm{r}=0,444$; $\mathrm{p}=0,001 ; \mathrm{p}<0,01)$. Zayıf bir ilişki olsa da çalışma yapılan işletmelerde iş güvenliği liderliği arttıkça, iş güvenliği ikliminin artacağı söylenebilir.

" $\mathrm{H}_{1}$ : iş güvenliği liderliği ile iş güvenliği iklimi arasında pozitif olarak anlamlı bir ilişki vardır." hipotezi kabul edilmiştir.

İş güvenliği liderlik ölçeği toplam puanı ile iş güvenliği iklimi eylem faktörü puanı arasında pozitif yönlü istatistiki olarak anlamlı orta düzeyde ilişki saptanmıştır $(\mathrm{r}=0,556$; $\mathrm{p}=0,001 ; \mathrm{p}<0,01)$. Çalışma yapılan işletmelerde iş güvenliği liderliği arttıkça iş güvenliği iklimi eyleminin artacağı söylenebilir.

" $\mathrm{H}_{1 \mathrm{a}}$ : iş güvenliği liderliği ile iş güvenliği iklimi eylem faktörü arasında pozitif olarak anlamlı bir ilişki vardır.” hipotezi kabul edilmiştir.

İş güvenliği liderlik ölçeği toplam puanı ile iş güvenliği iklimi beklenti faktörü puanı arasında negatif yönlü (toplam liderlik puanı arttıkça, beklenti puanı azalan) istatistiki olarak anlamlı çok zayıf ilişki saptanmıştır $(\mathrm{r}=-0,120 ; \mathrm{p}=0,014$; $\mathrm{p}<0,05$ ). Burada çok zayıf bir ilişki olsa da çalışma yapılan işletmelerde iş güvenliği liderliği arttıkça, iş güvenliği iklimi beklentisinin azalacağı söylenebilir.

" $\mathrm{H}_{\mathrm{b}}$ : iş güvenliği liderliği ile iş güvenliği iklimi beklenti faktörü arasında pozitif olarak anlamlı bir ilişki vardır." hipotezi kabul edilmemiş̧ir.

İş güvenliği liderlik ölçeği ile iş güvenliği davranış ölçeği puanları ilişkisi;

İş güvenliği liderlik ölçeği toplam puanı ile iş güvenliği davranışı toplam puanı arasında pozitif yönlü istatistiki olarak anlamlı orta düzeyde ilişki saptanmıştır $(\mathrm{r}=0,534 ; \mathrm{p}=0,001$; $\mathrm{p}<0,01)$. Çalışma yapılan işletmelerde iş güvenliği liderliği arttıkça, olumlu yönde iş güvenliği davranışı sergilemenin artacağı söylenebilir.

" $\mathrm{H}_{2}$ : iş güvenliği liderliği ile iş güvenliği davranışı arasında pozitif olarak anlamlı bir ilişki vardır." hipotezi kabul edilmiştir.

İş güvenliği liderlik ölçeği toplam puanı ile iş güvenliği uyum davranış puanı arasında pozitif yönlü istatistiki olarak anlamlı zayıf ilişki saptanmıştır $(\mathrm{r}=0,459 ; \mathrm{p}=0,001 ; \mathrm{p}<0,01)$. Zayıf bir iliş̧i olsa da çalışma yapılan işletmelerde iş güvenliği liderliği arttıkça, iş güvenliği uyum davranışının artacağı söylenebilir.

" $\mathrm{H}_{2 \mathrm{a}}$ : iş güvenliği liderliği ile iş güvenliği uyum davranış1 arasında pozitif olarak anlamlı bir ilişki vardır." hipotezi kabul edilmiştir.
İs güvenliği liderlik ölçeği toplam puanı ile iş güvenliği katılım davranış puanı arasında pozitif yönlü istatistiki olarak anlamlı zayıf ilişki saptanmıştır $(\mathrm{r}=0,499 ; \mathrm{p}=0,001 ; \mathrm{p}<0,01)$. Zayıf bir ilişki olsa da çalışma yapılan işletmelerde iş güvenliği liderliği arttıkça, iş güvenliği uyum davranışının artacağı söylenebilir.

" $\mathrm{H}_{2 b}$ : iş güvenliği liderliği ile iş güvenliği katılım davranışı arasında pozitif olarak anlamlı bir ilişki vardır." hipotezi kabul edilmiştir.

İş güvenliği iklim ölçeği ile iş güvenliği davranış ölçeği puanları ilişskisi;

İş güvenliği iklimi ölçeği toplam puanı ile iş güvenliği davranış ölçeği toplam puanı arasında pozitif yönlü istatistiki olarak anlamlı zayıf ilişki saptanmıştır $(\mathrm{r}=0,413 ; \mathrm{p}=0,001$; $\mathrm{p}<0,01)$. Zayıf bir ilişski olsa da çalışma yapılan işletmelerde iş güvenliği iklimi yükseldikçe, olumlu yönde iş güvenliği davranışı sergilemenin artacağı söylenebilir.

" $\mathrm{H}_{3}$ : iş güvenliği iklimi ile iş güvenliği davranışı arasında pozitif olarak anlamlı bir ilişki vardır." hipotezi kabul edilmiştir.

İş güvenliği iklim eylem faktör puanı ile iş güvenliği uyum davranış puanı arasında pozitif yönlü istatistiki olarak anlamlı zayıf ilişki saptanmıştır $(r=0,364 ; p=0,001 ; p<0,01)$. Zayıf bir ilişki olsa da çalışma yapılan işletmelerde iş güvenliği iklim şartları yükseldikçe, iş güvenliği uyum davranışının artacağı söylenebilir.

" $\mathrm{H}_{3 a}$ : iş güvenliği iklimi eylem faktörü ile iş güvenliği uyum davranışı arasında pozitif olarak anlamlı bir ilişki vardır." hipotezi kabul edilmiştir.

İş güvenliği iklim eylem faktör puanı ile iş güvenliği katılım davranış puanı arasında pozitif yönlü istatistiki olarak anlamlı zayıf ilişki saptanmıştır $(r=0,466 ; p=0,001 ; p<0,01)$. Zayıf bir ilişki olsa da çalışma yapılan işletmelerde iş güvenliği iklimi eylem boyutu yükseldikçe, iş güvenliği katılım davranışının artacağı söylenebilir.

" $\mathrm{H}_{3 b}$ : iş güvenliği iklimi eylem faktörü ile iş güvenliği katılım davranışı arasında pozitif olarak anlamlı bir ilişki vardır." hipotezi kabul edilmiştir.

İş güvenliği iklim beklenti faktörü puanı ile iş güvenliği uyum davranış puanı arasında negatif yönlü istatistiki olarak anlamlı çok zayıf ilişki saptanmıştır $(\mathrm{r}=-0,195 ; \mathrm{p}=0,001$; $\mathrm{p}<0,01)$. Çok zayıf bir ilişki olsa da çalışma yapılan işletmelerde iş güvenliği iklim şartları yükseldikçe, iş güvenliği uyum davranışı sergilemenin azalacağı söylenebilir.

" $\mathrm{H}_{3 c}$ : iş güvenliği iklimi beklenti faktörü ile iş güvenliği uyum davranışı arasında pozitif olarak anlamlı bir ilişki vardır." hipotezi kabul edilmemiştir.

İş güvenliği iklim beklenti faktör puanı ile iş güvenliği katılım davranış puanı arasında istatistiki olarak anlamlı ilişki saptanmamıştır $(\mathrm{p}>0,05)$. 
" $\mathrm{H}_{3 \mathrm{~d}}$ : iş güvenliği iklimi beklenti faktörü ile iş güvenliği katılım davranışı arasında pozitif olarak anlamlı bir ilişki vardır." hipotezi kabul edilmemiştir.

\section{Sonuç}

$\mathrm{Bu}$ çalışma Tekirdağ ilinde, tekstil imalat sektöründe faaliyet gösteren üç farklı işletmede gerçekleştirilmiştir. Çalışmada çalışanların iş güvenliği liderliği ve iş güvenliği iklimi algıları ile sergiledikleri iş güvenliği davranışları arasındaki ilişki tespit edilmeye çalışılmıştır.

Çalışmanın gerçekleştirildiği işletmelerde erkek çalışanların $(\% 69,2)$ fazla olduğu görülmüştür. Yaş aralıklarında ise 31-44 yaş aralığında $(\% 59,9)$ çalışan sayısının en çok olduğu tespit edilmiştir. Çalışmada evli olan çalışanların yüzdesi \%83,4 olarak ortaya çıkmıştır. Çalışmaya katılanların eğitim durumlarına bakıldığında ise çalışanlar ağırlıklı olarak lise mezunudur $(\% 52,9)$. Çalışma yapılan katılımcıların \%92,3’ü çalışan/operatördür. Çalışma yapılan işletmelerde iş güvenliği eğitimi alma durumuna göre ise çalışanların \%1,7'si $(n=7)$ iş güvenliği eğitimi almadıklarını belirtmiştir. Yapılan birebir görüşmelerde üretim sıkışıklığı, bazı spesifik makinelerde çalışan yedeklemesi olmaması ve sürekli benzer konuların anlatıldığ 1 ve konuların bilindiğinin iddia edilmesi nedenleriyle eğitimlere katılım sağlanmadığı bilgisi alınmasına karşın iş verenlerin, iş güvenliği eğitimine her ne sebeple olursa olsun çalışanı gönderme ve çalışanların da iş güvenliği eğitimlerine katılma sorumluluğu bulunduğunu hatırlatmak gerekir.

İş güvenliği liderliği, iş güvenliği iklimi ve iş güvenliği davranışı arasındaki ilişkilere bakıldığında ise, iş güvenliği liderliği ile iş güvenliği iklimi beklenti faktörü arasındaki ilişki haricinde tüm ilişkilerin pozitif ve anlamlı olduğu görülmüştür. $\mathrm{Bu}$ bize, iş güvenliği liderliğinin etkin olarak gösterildiği ve var olduğu işletmelerde, yönetimin iş güvenliği iklimini oluşturmadaki eylemlerinin yükseldiğini göstermektedir. Ayrıca iş güvenliği liderliğinin etkin olarak görüldüğü iş yerlerinde, çalışanların sergiledikleri iş güvenliği uyum ve katılım davranışları ile toplam iş güvenliği davranışları olumlu seyretmektedir. Metal sektöründe Acar (2019) tarafından yapılan benzer bir çalışmada da iş güvenliği liderliği etkin olduğunda iş güvenliği uyum ve katılım davranışlarının arttığı ifade edilmiştir.

İş güvenliği iklimi ile iş güvenliği davranışı arasındaki ilişki incelendiğinde ise makro düzeyde iş güvenliği iklimi yüksek olan işletmelerde olumlu iş güvenliği davranışı sergileme eğilimi yükselmektedir. Bununla beraber mikro düzeydeki ilişsilerde farklılıklar çıkmaktadır. İşletme yönetimlerinin iş güvenliği iklimi oluşturmak için gerçekleştirdikleri eylemlerin, çalışanların iş güvenliği davranışlarını olumlu yönde etkilediği görülmektedir. Ancak yönetimlerden iş güvenliği iklimini oluşturmak için yapması beklenen görevler, çalışanların iş güvenliği kurallarına uymalarını olumlu yönde etkilemediği hatta ters yönde etkilediği görülmüştür. Yönetimlerin iş güvenliği iklimi oluşturmakta yetersiz kaldığı, çalışanların da algılarında bu yetersizliği kolaylıkla saptanabildiği görülmüştür. Çalışanların iş güvenliğine katılım göstermelerinde ise yönetimlerin oluşturmaya çalıştıkları iş güvenliği iklimi ile hiçbir ilişkileri bulunmamaktadır.

Sonuç olarak tekstil imalat endüstrisinde çalışanların, iş güvenliği liderliği algılarının yüksek olduğu ve iş güvenliği liderliğinin iş güvenliği davranışlarını olumlu etkilediği görülmektedir. Etkin ve güçlü bir iş güvenliği liderliğinin, iş yerinin iş güvenliği iklimini yükseltmede rolü olduğu söylenebilir. Buradan yola çıkılarak, iş yeri iş güvenliği iklim seviyesi düşük olan işletmelerin, etkin ve güçlü iş güvenliği liderliği ile bu seviyeleri yükseltebilecekleri ifade edilebilir. $\mathrm{Bu}$ olumlu sonuçların yanında, iş güvenliği ikliminin beklenti faktörü ile iş güvenliği liderliği ve iş güvenliği uyum davranışı arasında negatif bir ilişki, iş güvenliği katılım davranışında ise hiçbir ilişki saptanmamıştır. $\mathrm{Bu}$ bize iş güvenliği iklimini oluşturmakta yönetimlerin daha fazla çaba sarf etmesi gerektiğini göstermektedir. Yönetimlerin, iş güvenliği iklimini yükseltmek için yapmaları gerekenler analiz edilerek, iş güvenliği iklimi algısının artırılmasında yapılabilecek çalışmalar ayrı bir araştırma konusu olarak önerilebilir.

\section{Kaynakça}

Acar, H. (2019). İş güvenliği liderliği, iş güvenliği iklimi ve iş güvenliği davranışı arasındaki ilişki: metal üretim sektöründe bir araştırma. Yüksek Lisans Tezi, Marmara Üniversitesi Sosyal Bilimler Enstitüsü İşletme Anabilim Dalı İnsan Kaynakları Yönetimi Bilim Dalı, İstanbul, Türkiye, 111.

Akarsu, B. \& Akarsu, B. (2019). Bilimsel Araştırma Tasarımı. İstanbul: Cinius Yayınları, 4.

Alruqi, W. M., Hallowell, M. R. and Techera, U. (2018). Safety climate dimensions and their relationship to construction safety performance: A meta-analytic review. Safety science, 109, 165-173.

Altunışık, R., Coşkun, R., Bayraktaroğlu, S. ve Yıldırım, E. (2005). Sosyal Bilimlerde Araştırma Yöntemleri. Sakarya: Sakarya Kitabevi, 217.

Ashkanasy, N.M. ve Jackson C.R.A. (2009). Örgüt Kültürü ve İklimi. Anderson N., Öneş D.S., Sinangil H.K., Viswesvaran C. (Ed.) Endüstri, İş ve Örgüt Psikolojisi El Kitabı (2. Cilt), (463-483). İstanbul: Literatür Yayınc1lık.

Aytaç, M. ve Öngen, B. (2012). Doğrulayıcı faktör analizi ile yeni çevresel paradigma ölçeğinin yap1 geçerliliğinin incelenmesi. Ístatistikçiler Dergisi: Istatistik ve Aktüerya, 5(1), 14-22.

Barling, J., Loughlin, C. and Kelloway, E. K. (2002). Development and test of a model linking safety-specific transformational leadership and occupational safety. Journal of applied psychology, 87(3), 488-496.

Bayat, B. (2010). Pozitivist Sosyal Bilim Araştırmalarında Doğrulama ve Genelleme; Epistemolojik Bir İnceleme. Çalışma İlişkileri Dergisi, 7(1), 1-11.

Bosak, J., Coetsee, W. J. and Cullinane, S. J. (2013). Safety climate dimensions as predictors for risk behavior. Accident Analysis \& Prevention, 55, 256-264.

Büyüköztürk, Ş., Çokluk, Ö. \& Köklü, N. (2020). Sosyal bilimler için istatistik. Ankara: Pegem Akademi, 79.

BSMS. (2020). Safety Behavior. http://www.behaviouralsafety.com/b-safe-management-solutions/ourapproach/safety-behavior/ (Erişim tarihi: 24.08.2020)

Can, A. (2019). SPSS ile bilimsel araştırma sürecinde nicel veri analizi. Ankara: Pegem Akademi, 325.

Casey, T. W., \& Griffin, M. A. (2020). Lead Safety: A Practical Handbook for Frontline Supervisors and Safety Practitioners. CRC Press, 1.

Cooper, D. (1998). Improving safety culture: A practical guide. Chichester: Wiley, 30.

Coyle, I. R., Sleeman, S. D. and Adams, N. (1995). Safety climate. Journal of Safety research, 26(4), 247-254. 
ÇSGB İSGGM. (2017). Tekstil Sektörü İş Sağlığ1 ve Güvenliği Yönetim Sistemi Rehberi. https://www.ailevecalisma.gov.tr/medias/7043/tekst\%C4\%B 01-sektoer\%C3\%BC-\%C4\%B0sgys-rehber\%C4\%B0.pdf (Erişim tarihi: 19.04.2021)

Demir, S.B. \& Akengin, H. (2010). Sosyal Bilgiler Dersine Yönelik Bir Tutum Ölçeğinin Geliştirilmesi: Geçerlik ve Güvenirlik Çalışması. E-Uluslararası Ĕgitim Araştırmaları Dergisi, 1(1), 26-40.

Donovan, S. L., Salmon, P. M. and Lenné, M. G. (2016). Leading with style: a literature review of the influence of safety leadership on performance and outcomes. Theoretical Issues in Ergonomics Science, 17(4), 423-442.

Dursun, Y. \& Kocagöz, E. (2010). Yapısal Eşitlik Modellemesi ve Regresyon: Karşılaştırmalı Bir Analiz. Erciyes Üniversitesi İktisadi ve İdari Bilimler Fakültesi Dergisi, (35), 1-17.

Efe, Ö.F. (2018). Tekstil sektöründe iş kazalarının ve meslek hastalıklarının üretime ve kaliteye etkilerinin incelenmesi. Doktora Tezi, Sakarya Üniversitesi, Fen Bilimleri Enstitüsü, Sakarya, Türkiye, 21.

Ergin, H., \& Mergen, A. (2017). Hazır giyim mağazacılık sektöründe iş kazaları ve çözüm önerileri: Örnek bir uygulama. Marmara Fen Bilimleri Dergisi, 29(1), 29-38.

Erilli, N.A. (2015). İstatistik-2. Ankara: Seçkin Yayınları, 218.

Griffin, M. A., \& Neal, A. (2000). Perceptions of safety at work: a framework for linking safety climate to safety performance, knowledge, and motivation. Journal of occupational health psychology, 5(3), 347.

Hackitt, J. (2013). Committing afresh to a global safety culture. http://app.croneri.co.uk/feature-articles/piper-alpha-25years/ (Erişim tarihi: 27.08.2020)

Hair, J. F., Anderson, R. E., Tahtam, R. L. and Black, W. C. (1998). Multivariate Data Analysis. New Jersey: Prentice Hall International Inc., 374.

Hofmann, D. A., Burke, M. J. and Zohar, D. (2017). 100 years of occupational safety research: From basic protections and work analysis to a multilevel view of workplace safety and risk. Journal of applied psychology, 102(3), 375-388.

Hofmann D.A. \& Morgeson F.P. (2004). The Role of Leadership in Safety, in Barling, J. E., \& Frone, M. R. (Ed.) The Psychology of Workplace Safety. (159-177). American Psychological Association.

Karagöz, Y. (2014). SPSS 21.1 Uygulamall Biyoistatistik. Ankara: Nobel Akademik Yayınc1lik, 698.

Kurt, T., \& Çalık, T. (2010). Okul iklimi ölçeği'nin (OİÖ) geliştirilmesi. Eğitim ve Bilim, 35(157).

Mirza, M. Z. and Isha, A. S. N. (2017). Context matters: A research agenda to move beyond conventional leadershipsafety relationship. Safety Science, 98, 167-173.

Moon, K., Lee, J., \& Oah, S. (2013). The effects of safety leadership of manager and safety climate in the organization on the workers' safety behaviors. Journal of the Korean Society of Safety, 28(2), 66-72.

Mullen, J. E., \& Kelloway, E. K. (2009). Safety leadership: A longitudinal study of the effects of transformational leadership on safety outcomes. Journal of occupational and organizational psychology, 82(2), 253-272.

Neal, A., \& Griffin, M. A. (2002). Safety climate and safety behaviour. Australian journal of management, 27(1_suppl), 67-75.
Neal, A., Griffin, M. A., \& Hart, P. M. (2000). The impact of organizational climate on safety climate and individual behavior. Safety science, 34(1-3), 99-109.

Olcay, Z. F. (2021). İş Sağlığı ve Güvenliği Kültürü Ölçeği; Geçerlik ve Güvenirlik Çalışması. Avrupa Bilim ve Teknoloji Dergisi, (23), 678-685.

Olcay Z.F., Temur S., \& Sakalli A.E. (2021). A research on the knowledge level and safety culture of students taking occupational health and safety course. Cypriot Journal of Educational Sciences, 16(1), 187-200.

Osmanoğlu, H., Üzüm, H., Karlı, Ü. ve Aycan, A. (2018). Spor Turizmi Hizmet Kalitesi Ölçeği Geçerlik ve Güvenirlik Çalışması. International Journal of Economic \& Social Research, 14(1), 121-134.

Pilbeam, C., Doherty, N., Davidson, R. and Denyer, D. (2016). Safety leadership practices for organizational safety compliance: Developing a research agenda from a review of the literatüre. Safety Science, 86, 110-121.

Ramnerö, J. \& Törneke N. (2017). İnsan Davranışlarının $A B C$ si. İstanbul: Litera Yayıncılık, 26.

Sharma, S. (1996). Applied Multivariate Techniques. New York: Jhonn Wiley \& Sons Inc., 116.

Şencan, H. ve Fidan, Y. (2020). Likert Verilerinin Kullanıldığ 1 Keşfedici Faktör Analizlerinde Normallik Varsayımı ve Faktör Çıkarma Üzerindeki Etkisinin SPSS, Factor ve Prelis Yazilımlarıyla Sinanmasi. Business \& Management Studies: An International Journal, 8(1), 640-687.

SGK, (2020). SGK İstatistik Yıllıkları. http://www.sgk.gov.tr/wps/portal/sgk/tr/kurumsal/istatistik/s gk istatistik yilliklari/ (Erişim tarihi: 16.09.2020)

Şişman, M. (2014). Örgütler ve Kültürler. Ankara: Pegem Akademi, 155.

Taşpınar, M. (2017). Sosyal Bilimlerde SPSS Uygulamalı Nicel Veri Analizi. Ankara: Pegem Akademi, 194.

Tavşancıl, E. (2002). Tutumların Ölçülmesi ve SPSS ile Veri Analizi. Ankara: Nobel Yayınc1lık, 50.

Temel, B. (2020). İş sağlığı ve güvenliği uygulamalarının yapısal eşitlik modeli kullanılarak iş ortamındaki parametreler üzerine etkisinin araştırılması: Elektrik-elektronik sektöründe uygulama. Doktora Tezi, İstanbul Aydın Üniversitesi, Lisansüstü Eğitim Enstitüsü İş Sağllğı ve Güvenliği Bilim Dal, İstanbul, Türkiye.

Tezcan, C. (2008). Yapısal Eşitlik Modelleri. Yüksek Lisans Tezi, Hacettepe Üniversitesi Fen Bilimleri Enstitüsü İstatistik Anabilim Dalı, Ankara, Türkiye.

Türkiye İhracatçılar Meclisi (TIM). (2020). https://tim.org.tr/tr/ihracat-rakamlari (Erişim tarihi: 19.04.2021)

Ticaret Bakanlığı İhracat Genel Müdürlüğü. (2020). Hazır Giyim Sektör Raporu. https://ticaret.gov.tr/data/5b87000813b8761450e18d7b/Haz \%C4\%B1r\%20Giyim\%20Sekt\%C3\%B6r\%C3\%BC_2018.p df (Erişim tarihi: 19.04.2021)

Ullman, J.B. (2015). Yapısal Eşitlik Modelleme. Tabachnick, B. G., and Fidell, L. S. (Ed.) Çok Değişkenli İstatistiklerin Kullanımı, (681-785), Ankara: Nobel.

Wu, T.C. (2005). The validity and reliability of safety leadership scale in universities of Taiwan. International Journal of Technology and Engineering Education, 2(1), 27-42.

Zohar, D. (2000). A group-level model of safety climate: testing the effect of group climate on microaccidents in manufacturing jobs. Journal of Applied Psychology, 85(4), 587-596. 